Research Report No. 7/2010

\title{
Negotiating the Claim to Inclusion: Statelessness and the Contestation of the Limits of Citizenship
}

Kiran Banerjee

Follow this and additional works at: http:/ / digitalcommons.osgoode.yorku.ca/clpe

\section{Recommended Citation}

Banerjee, Kiran, "Negotiating the Claim to Inclusion: Statelessness and the Contestation of the Limits of Citizenship" (2010). Comparative Research in Law \& Political Economy. Research Paper No. 7/2010.

http://digitalcommons.osgoode.yorku.ca/clpe/76 


\title{
OSGOODE
}

OSGOODE HALL LAW SCHOOL

YOR K UN I VERSITY

\section{OSGOODE HALL LAW SCHOOL}

Comparative Research in Law \& Political Economy

\author{
RESEARCH PAPER SERIES
}

Research Paper No. 07/2010

\section{Negotiating the Claim to InCLUSION: StateleSSNESS AND THE CONTESTATION OF THE LIMITS OF CITIZENSHIP}

Kiran Banerjee

\section{Editors:}

Peer Zumbansen (Osgoode Hall Law School, Toronto, Director, Comparative Research in Law and Political Economy)

John W. Cioffi (University of California at Riverside)

Lisa Philipps (Osgoode Hall Law School, Associate Dean Research)

Nassim Nasser, Ahmed Hassan (Osgoode Hall Law School, Toronto, Production Editors) 
CLPE Research Paper 07/2010

Vol. 06 No. 2 (2010)

Kiran Banerjee

\title{
Negotiating the Claim to Inclusion: Statelessness and the Contestation of the Limits of Citizenship
}

\begin{abstract}
This paper addresses how our conceptions of community and citizenship should be transfigured on account of the theoretical and ethical concerns revealed by statelessness. Taking my point of departure from the work of Hannah Arendt, I show how the phenomenon of statelessness reveals tensions in our conceptions of political membership and human rights, while highlighting the dilemmas that any approach to democratic inclusion must address. As Arendt's work emphasizes, one of the greatest challenges to the cosmopolitan ideal of realizing universal human rights is the way in which realizing rights claims is tied to political membership within a particular community. The crucial loss of a 'right to have rights' suffered by the stateless is not one of a 'natural' right but rather the loss of a right of belonging to a community within which such rights have meaning in the locus of citizenship. The paper then shifts from a diagnostic to a prescriptive focus, turning to Jurgen Habermas' notion of discourse ethics grounded in his account of communicative action as a means to theorize the issues raised by statelessness and the idea of a claim to community. While discourse ethics offers a useful framework, I argue that we need a supplementary orientation toward openness, given that statelessness has at its core the problem of inclusion. In addressing this more fundamental question of inclusion, I turn to contemporary theorists of agonistic democracy whose focus on the contestability of terms and the fundamentally unsettled nature of the political provide resources for conceptualizing more open notions of political membership. While noting the limitations of each approach, I conclude by showing how discourse ethics and agnostic theory can be used to imagine communities that eschew the exclusions that create statelessness.
\end{abstract}

Key Words: Law, Statelessness, Human rights, Habermas, Inclusion, Political membership, Discourse ethics, Agnostic theory

JEL code: K30, K33.

Kiran Banerjee

Doctoral candidate, Department of Political Science, University of Toronto 


\title{
Negotiating the Claim to Inclusion: Statelessness and the Contestation of the Limits of Citizenship
}

\author{
Kiran Banerjee*
}

\section{Contesting Community: The Refugee as a Site of Tension}

Writing in the mid-twentieth century with the horrors of the Second World War still close at hand, Hannah Arendt noted that the emergence of stateless persons as the "most symptomatic group in contemporary politics" served as both a catalytic factor in the emergence of totalitarianism and as a lasting crisis of the post-totalitarian world. Of course, since Arendt penned her farsighted observations, the oft referred to 'humanitarian problem' that refugees and stateless persons have been seen to pose has only become far more ubiquitous, with over 17 million people classified as refugees and displaced persons to date. ${ }^{1}$ Moreover, alongside the equally pressing international issues of immigration and humanitarian intervention, the questions posed by the phenomena of widespread statelessness has only intensified the degree to which commitments to universal human rights and the sovereign claims of political communities have been seen to clash, thereby complicating discussions of global justice and the emerging international legal norms of our increasingly interconnected present. Indeed, for our modern paradigm of human rights that has been philosophically advanced on universalistic grounds, and yet linked to the incorporation of such rights into national institutions and law, the refugee appears as a figure both least protected and most vulnerable under present international arrangements.

Yet despite the apparent challenges the position of the refugee appears to offer toward our contemporary understandings of citizenship and human rights, the issue of statelessness has received relatively little sustained attention within discussions of international justice. In many ways it appears as if the general consensus views statelessness as a status far too exceptional, and therefore peripheral, to merit direct concern. It is because of this general trend that this paper attempts in part to reorient normative political theory to the particular quandaries and

\footnotetext{
${ }^{*}$ Doctoral candidate, Department of Political Science, University of Toronto.
}

This paper was presented at the Third Annual Conference of the Toronto Group for the Study of International, Transnational, and Comparative Law 2010 and benefited greatly from the comments of participants. Additionally, I am grateful to Howard Adelman, Alexis Alchorn, Ishan Banerjee, Lindsay Knight, Aaron Meyer, Sean Rehaag, Melvin Rogers, and Stephen White for valuable comments and conversations on previous drafts.

${ }^{1}$ Given that there is an obvious political dimension to the classification of individuals as refugees, it is worth noting that the UNFPA estimates that there are over 190 million immigrants worldwide. 
issues raised by statelessness. This is because, as I hope to indicate herein, an inattentiveness to the position of the refugee often distorts or clouds discussions of international obligations and human rights, allowing us to gloss over the underlying inconsistencies in our prevailing understandings of international order and global justice. A central example of this "blind spot" in contemporary political theory is found in the later work of the seminal political theorist John Rawls. In his The Law of Peoples, an attempt to work out a theory of justice for international relations, Rawls entirely elides the ethical and political issues raised by immigration and statelessness-problematically articulating a vision of interstate relations that puts the imperatives of self-determination and human rights in stark conflict. In this way, Rawls' inattentiveness to the contingencies of citizenship is emblematic of the refusal to recognize the articulation of the basis and bounds of community membership as a central political question. Moreover, as much of the critical reception of The Law of Peoples has suggested, the problems raised by such issues can only be neglected at the cost of considerable conceptual poverty.

With the above considerations in mind, this paper will attempt to provide a provisional engagement with the particular issues raised by the position of the refugee and, more generally, to suggest that the questions of statelessness should occupy a far more central place in the considerations of normative political theory. In doing so, I will attempt to address whether, and if so how, our conceptions of community and citizenship should be transfigured on account of the particular theoretical and ethical concerns raised by statelessness. The first section will offer an account of the problematic status of the refugee by engaging with the work of Hannah Arendt to indicate how the phenomena of statelessness reveals hidden tensions in our conceptions of political membership and universal human rights. Arendt's incisive analysis brings to light the precarious position of the refugee as located out of the bounds of community, while also highlighting the particular dilemmas that any approach toward statelessness will have to address. The second section will shift focus from a diagnostic to a prescriptive dimension, by turning to the approach of discourse ethics offered in Jurgen Habermas' work as a potential means to theorize the issues raised by statelessness and the question of the claim or right to community. As will become clear, the approach offered by Habermas' is suggestive of novel ways of negotiating and transforming our conceptions of political membership toward a more just and cosmopolitan conception. However, while the paradigm of discourse ethics provides a promising framework, I will suggest that this approach is in need of a supplementary orientation toward openness, given that the question of statelessness has at its very core the problematic of inclusion. In addressing this more fundamental dimension of the question of inclusion, I shall turn to the work and insights of the contemporary theorists of agonistic democracy William Connolly and Chantal Mouffe. As will become clear, the focus of these theorists on the contestability of terms and the fundamentally unsettled nature of the political provide resources for conceptualizing more open notions of political membership. The paper will conclude by suggesting how the approaches of discourse ethics and agnostic theory can be used to imagine formations of community that eschew the types of exclusion central to the production of statelessness. 


\section{The Problematic of Statelessness: Sovereignty AND Human RightS}

Having established our trajectory of analysis, our engagement with the issue of statelessness will begin by turning to the work of Hannah Arendt. Her thought offers a unique perspective on our contemporary historical situation that importantly challenges our orientation toward the relationship of human rights and citizenship, providing a remarkable vantage point from which to consider such problems anew. Arguably, the figure of the refugee is central to Arendt's concerns regarding our forms of modern politics and community, in part driving her critical analysis in both The Origins of Totalitarianism and The Human Condition. However, it is in the former work that the situation of the refugee is given most explicit treatment, and it is to Arendt's analysis of the emergence of mass statelessness that I shall now turn to in order to briefly explicate the problematic concerns raised by such phenomena.

As a project, The Origins of Totalitarianism represents Arendt's attempt to understand the historically unprecedented emergence of totalitarianism in the 20th Century through an extensive study of the diffuse conditions under which it arose. In her study, Arendt specifically identifies the emergence of widespread statelessness - the rendering of masses of people as rightless and uprooted-as one among many conditions that made possible the horrors of total domination in the modern world. Indeed, with the appearance of the refugee or stateless person as a pervasive phenomenon, many of the previously submerged dangers and contradictions of the nation-state system came to the fore-perhaps most importantly in the conceptual and practical crisis inherent in the notion of inalienable universal human rights. In her discussion subtitled "The Decline of the Nation-State and the End of the Rights of Man" Arendt offers a consideration of the phenomena of widespread statelessness during the interwar era that delineates her views of the crucial implications of such developments.

Arendt's analysis begins by tracing the emergence of modern statelessness to the moment at which governments of the European continent began the theretofore unheard of process of revoking the citizenship of segments of their populations en masse. With such developments the figure of the 'Refugee' emerged in Europe: a stateless individual lacking any governmental protection. Arendt notes that the sudden presence of mass statelessness quickly proved to be more than the existing legal institutions of the nation-state system could accommodate. Both of the traditional remedies to the hitherto exceptional position of the exile, the right to asylum and naturalization, quickly came to conflict with the sovereign rights of the state and, without any grounding in positive law, were quickly disregarded. ${ }^{2}$ But what was perhaps most striking was the manner in which commitments to socalled 'human rights,' paradigmatically expressed in the Declaration of the Rights of Man, rapidly began to reveal their fragile and contingent basis amid such unprecedented developments.

In her discussion of the problematic nature of 'human rights' Arendt draws our attention to the basis on which these rights were proclaimed-namely an abstract conception of man generalized beyond his situation within a political community, a conception that depended on

\footnotetext{
${ }^{2}$ Hannah Arendt, The Origins of Totalitarianism (New York: Harcourt Brace Jovanovich, 1973), 280.
} 
the assumption that these rights derived from no other source than man's inherent nature. Any valid political system presupposed these rights, and thus needed to recognize them in order to govern legitimately. But as Arendt notes, within a political system the sole guarantor of these rights was the political sovereign itself. A tension arose, in that the very rights set forth as natural and thus prior to the sovereign, relied upon the sovereign for their protection within the political community.

What Arendt wished to emphasize is that the rights enshrined in such proclamations of human rights actually refer to civic rights that can only have significance in the context of membership in a political community. Therefore what was revealed in the phenomena of mass statelessness was the deep interrelation and dependency between so-called 'human rights' and membership rights within a polity. Thus the fundamental loss suffered by the rightless was not a loss of a natural, inalienable right. It was rather the loss of their right to belong to a community in which such rights could have meaning, and of a place in the world in which their words and actions would be taken into account. This 'right to have rights,' the fundamental right which the refugee lost, was completely absent from the framework of The Rights of Man. The very structure of such rights, in presupposing an abstract human nature as the source of their legitimacy, could not articulate or express this fundamental right whose alienation constitutes the denial of one's human dignity. Yet, as Arendt observed and to some degree experienced, it was precisely as a mere human, stripped of the markers of nationality and citizenship, that the refugee appeared. Moreover within Arendt's analysis the phenomenon of statelessness emerges as a symptom of the contradiction inherent between the expansion of the system of the nation-state and the earlier notion of inalienable rights arising out of man's nature. The genesis of this tension is exemplified in the French Revolution's simultaneous and, ultimately contradictory, expression of the Declaration of the Rights of Man and the demand for the national sovereignty of the people. The people were at once supposed to have universal rights and unlimited political power-but only as members of a nation, and therefore the sovereign political force therein. Arendt writes:

The same essential rights were at once claimed as the inalienable heritage of all human beings and as the specific heritage of specific nations, the same nation was at once declared to be subject to the laws, which supposedly would flow from the Rights of Man, and sovereign, that is, bound by no universal law and acknowledging nothing superior to itself. ${ }^{3}$

In her tracing of a genealogy of the modern nation state, we see that the crisis of modern statelessness, as precipitated by the exclusionary logic of what had been thought to be "human rights,' lies in this underlying tension between the state and the nation, as well as that between universal rights and civil rights. Arendt's analysis suggests that the phenomena of statelessness is not merely coeval with the rise of the nation-state system, but a direct extension of the logic of sovereignty that system is predicated upon. But what perhaps was most striking about the

\footnotetext{
${ }^{3}$ Hannah Arendt, The Origins of Totalitarianism, 230.
} 
position of the refugee was the way in which de-nationalization related to the conditions that underwrite the human ability to act inhumanely to others. Within Arendt's analysis the situation of the refugee is tantamount to the loss of the inter-subjective "modes in which human beings appear to each other, not indeed as physical objects, but qua men." ${ }^{4}$ Thus within Arendt's analysis the phenomena of statelessness is not only symptomatic of contemporary exclusionary modes of community and the concomitant tensions between human rights and state sovereignty, but actually constitutive of modalities of relatedness that allow human rights violations to take place.

As I have tried to emphasize above, the phenomena of statelessness is fundamentally tied to the tension we find between the universalizing impulse of human rights discourse and the limitations imposed by our current understandings of citizenship and the state. As the sociologist Saskia Sassen has noted of the developments of the inter-war era, "the emergent interstate system was the key to the creation of the stateless person, the identification of refugees as such, and their regulation or control. ${ }^{\prime 5}$ Indeed, perhaps what is most remarkable about Arendt's insights is how pertinent they remain for our contemporary situation. The primary international response to the issues posed by statelessness has been the constitution of intergovernmental organizations responsible for overseeing the condition of refugees-but these institutions are themselves symptomatic of the only intensified pervasiveness of statelessness within the world. Moreover, despite the presence of emerging norms concerning the question of humanitarian intervention, in which sovereignty has become understood as contingent upon the state's responsibility to protect, ${ }^{6}$ norms regarding the position of refugees and asylum seekers have become only more ambiguous in relation to the prerogatives of raison d'etat. Three remarkable, though by no means isolated, recent illustrations of the unresolved nature of these tensions clearly indicate the crucial limitations of modern human rights norms for dealing with such issues. The first has been the 2001-2008 Pacific Solution of the Australian government, under which a system of offshore detention centers were established for individuals entering the country without valid papers in order to provide greater discretion in the evaluation of asylum seekers without violating the human rights norms that come into effect with landed status. Such a system, which lived on in the country's mandatory detention policy, led to the pervasive long-term incarceration of asylum seekers and refugees. ${ }^{7}$ The second notable case is to be found in the intervening stages of the British Belmarsh decision of 2004 which allowed the UK government to detain indefinitely non-citizens who would normally face deportation, but who could not be deported without derogation from human rights

\footnotetext{
${ }^{4}$ Hannah Arendt, The Human Condition (Chicago: The University of Chicago Press, 1958), 176.

${ }^{5}$ Saskia Sassen, Guests and Aliens (New York: New Press, 2000), 84.

${ }^{6}$ Thomas Weiss, Humanitarian Intervention (Cambridge: Polity, 2007), 116.

7 Human Rights Watch, “'Not for Export' Why the International Community Should Reject Australia's Refugee Policies," September 2002.

Ian MacKinnon, “Australia opens controversial asylum centre on Christmas Island," The Guardian, December 19, 2008.
} 
obligations because of the risk they face of being tortured in their country of origin. ${ }^{8}$ The paradoxical outcome of this situation was the legalization of indefinite incarceration without trial for non-citizens under the aegis of conforming to human rights norms. More remarkable, at just the moment when institutional innovations such as the Schengen agreement in Europe are beginning to supposedly de-territorialize states and breakdown borders, "detention camps for foreigners have mushroomed across the European Union" with experiments with the externalization of borders along the lines of the 'Pacific Solution' already beginning to take form through multilateral agreements with bordering states. ${ }^{9}$ While these cases provide extreme examples of the conflict between human rights norms and state sovereignty within the policies of advanced industrial democracies, they are merely emblematic of general contradictory features of our international system. Civil wars, natural disasters, widespread poverty and failed states, amid a world of only tightening borders have only increased the number of people caught between the interstices of our international order.

I would contend, along with Arendt, that the underlying source of our contemporary inability to manage these pathologies of the nation state system lie in the exclusionary nature of our current forms of citizenship and our inability to recognize the fundamental nature of the right to belong to a community. Indeed, what is perhaps most remarkable about our current era of globalization is that, with supposedly growing mobility and interconnectedness across the world, the ability of human persons to move across borders would pale in comparison to that of international trade and monetary exchange. The costs of this contradictory logic are of course born heavily by those who find themselves on the outside of states, or as the 'others' of the citizens within nations. But while Arendt's work brings to the fore the untenable nature of our current conceptions of community and the fundamental limitations of human rights discourse, her insightful analysis provides us with only a problematization of the issues at hand. ${ }^{10}$

\section{DiscouRSE Ethics AND the Right to BELONG:}

Having provided a provisional sketch of the problematic conceptual challenges raised by the phenomena of statelessness, I would now like to turn to the theoretical approach toward these

\footnotetext{
${ }^{8}$ David Dyzenhaus, The Constitution of Law: Legality in a Time of Emergency (Cambridge: Cambridge University Press, 2006), 31.

${ }^{9}$ Caroline Brother, “Obscurity and confinement for migrants in Europe," International Herald Tribune, December 30, 2007.

${ }^{10}$ I have elsewhere argued that Arendt's work implicitly contains a response to the paradox posed by statelessness in her critique of sovereignty. But I have begun to have doubts whether such an account is a sufficient enough basis for theorizing substantive solutions to the problems posed by statelessness. Hence this paper, which takes Arendt's work as a starting point for engaging with more disparate perspectives.
} 
issues that can be articulated through an engagement with Habermas' work, in particular the mode of philosophical justification he has developed under the rubric of discourse ethics. The salience of Habermas' thought for addressing the conceptual problems of statelessness raised initially by Arendt is suggested by the critical edge discourse ethics potentially offers for interrogating and dislodging the presuppositions that currently underpin our exclusionary conceptions of 'belonging' necessary to the production of statelessness. Indeed, in the way they are entwined with the ideas of community, citizenship and human rights, the issues of inclusion raised by statelessness seem to be intimately tied to "questions having to do with the grammar of forms of life" in our late modern era. ${ }^{11}$ Moreover the broader focus of his larger project of the theory of communicative action, with its focus on intersubjective engagement and attentiveness to the distorting effects of power relations, further confirm the promise of appealing to his work within the context of our present discussion. ${ }^{12}$

In taking up Habermas' approach of discourse ethics for the issue of statelessness, I will interpret Habermas as a post-metaphysical, non-foundationalist theorist. ${ }^{13}$ Based on this reading, I suggest the promise of his approach lies in providing a conceptualization of the issues raised by statelessness and citizenship without having to rely upon problematic philosophical or metaphysical assumptions that often seem to underpin our understanding of human rights. Given the cautionary warning that Arendt's analysis offers regarding the fragility of such premises, a theoretical commitment to non-foundationalism in our conceptual approach seems most prudent and promising. Granted, this reading of Habermas as eschewing foundationalism in his approach to communicative action is somewhat complicated by his apparent essentialism regarding the nature of language as having as its "inherent telos" the reaching of mutual understanding. ${ }^{14}$ However the apparent import of such accusations of a hidden foundationalism are themselves seemingly overstated. ${ }^{15}$ Moreover, regardless of whether we are fully sanctioned in interpreting Habermas' theoretical commitments in this way, I believe we can easily take up his position while still acknowledging that his account of language may merely have the status of, to use Connolly's phrase, "premises deeply rooted in modernity

\footnotetext{
${ }^{11}$ Jürgen Habermas, The Theory of Communicative Action, Volume 2: Lifeworld and System: A Critique of Functionalist Reason, trans. T. McCarthy (Boston: Beacon Press, 1985), 392.

${ }^{12}$ Such de-centered and inter-subjective features of Habermas' approach are in marked contrast to the conceptual lineage we find in the work of John Rawls, whose subject-centered approach clearly has it's roots in Kantian moral philosophy. Given the marked inattentiveness of Rawls' work on global justice to the questions raised by statelessness, such divergences are suggestive of the potential of discourse ethics.

13 Jürgen Habermas, The Theory of Communicative Action, Volume 2, 387-8.

14 Jürgen Habermas, The Theory of Communicative Action, Volume 1: Reason and the Rationalization of Society, trans. T. McCarthy (Boston: Beacon Press, 1985), 287.

${ }^{15}$ This reading of Habermas seems to be vindicated by his claim to be adopting the position of someone "operating without metaphysical support and is also no longer confident that a rigorous transcendental-pragmatic program, claiming to provide ultimate grounds, can be carried out." (Theory of Communicative Action, Volume 1, 137)
}

See also: Simone Chambers, Reasonable Democracy, 111-16, for a related discussion of the "hypothetical and fallible" universalism of Habermas' approach. 
itself." ${ }^{16}$ Moreover, the appropriation of an approach said to be rooted in the emergence of modernity itself seems entirely appropriate for interrogating the distinctively modern forms of community and collective identity that are implicated in the production of statelessness. ${ }^{17}$

In turning to Habermas' framework, we should begin by recognizing that the approach of discourse ethics is best understood as an extension of the conception of communicative 'rationality' presented in The Theory of Communicative Action. The conception of communicative rationality, according to Habermas, "carries with it connotations based ultimately on the central experience of the unconstrained, unifying, consensus bringing force of argumentative speech. ${ }^{18}$ Appealing to our everyday intuitions, Habermas points to the basis of this conception of rationality in our ability to give reasons or justifications for certain modes of action or statements about our social world, a tendency that Habermas explicitly links up with the redeeming of normative claims. ${ }^{19}$ In reconstructing a moral theory from the suppositions of unconstrained argumentative discourse, Habermas begins with the constrained assumption that normative claims can be redeemed in a way analogous to truth claims ${ }^{20}$ The weakening of the cognitivist commitments of Habermas' approach and the consequent limiting of the transcendental scope of discourse ethics to "give up any claim to "ultimate justification" is itself consistent with understanding of norms that Habermas attributes to the post-conventional era of modernity. ${ }^{21}$ The approach of discourse ethics is therefore best understood as the working out of implications of his conception of communicative rationality in relation to claims of normative validity and moral legitimacy. As Thomas McCarthy notes, for Habermas the elaboration of the principles of ethics justification "begins with a reflective turn, for these principles are built into the very structure of practical discourse itself." ${ }^{\prime 2}$ Therefore it is the model of argumentative discourse that provides the principle of discourse ethics, that "only those norms can claim to be valid that meet (or could meet) with the approval of all affected in their capacity as participants in a practical discourse." ${ }^{23}$ The principle of discourse ethics

\footnotetext{
${ }^{16}$ William Connolly, The Terms of Political Discourse (Princeton: Princeton University Press, 1974), 241.

${ }^{17}$ The relation between the approach of discourse ethics as an extension of communicative action to the conditions of modernity is clear from its dependency on the world differentiation that Habermas attributes to shift to modernity. See Jürgen Habermas, Theory of Communicative Action, Volume 1, 52.

${ }^{18}$ Jürgen Habermas, The Theory of Communicative Action, Volume 1, 10.

19 Jürgen Habermas, The Theory of Communicative Action, Volume 1, 8.

20 Jürgen Habermas, Moral Consciousness and Communicative Action, trans. C. Lenhardt and S. Nicholsen. (Cambridge: The MIT Press, 2001), 76

${ }^{21}$ Jürgen Habermas, Moral Consciousness and Communicative Action, 77.

${ }^{22}$ Thomas McCarthy, The Critical Theory of Jürgen Habermas (Cambridge: The MIT Press, 1981), 324.

${ }^{23}$ Jürgen Habermas, Moral Consciousness and Communicative Action, 66.
} 
therefore stipulates the intersubjective condition under which a norm can be justified as expressing the common will of the plurality of those who will be effected.

Before turning toward the application of discourse ethics within our current context, it is important to note the relation of Habermas' approach to the tradition of Kantian moral theory, if only to stress its crucial divergences. As a deontological approach, Kant's monistic oriented moral theory attempts to avoid the issue of conflicting obligations by claiming to show that the categorical imperative itself is adequate as a moral standard for validating norms or maxims. In this way the Habermassian approach can be seen as an extension of the Kantian tradition with notable modifications: the rejection of the metaphysical division of the world into the nominal and the phenomenal realm, and the insistence on a dialogical basis for moral consciousness. For Habermas the criteria is, contra Kant, not what the individual can will without contradiction, but what all affected parties can agree to in rationally grounded discourse. Key to Habermas' approach is the way he construes the universalizing dimension of moral discourse in a decentered fashion. Hence the criteria of impartiality for discourse ethics, taken from the suppositions of everyday communication, is captured in the principle of universalism for the validity of every norm, such that: "All affected can accept the consequences and the side effects its general observance can be anticipated to have for the satisfaction of everyone's interests." ${ }^{24}$ This is because Habermas identifies the fault in Kantian approaches to the principle of universalization as lying in the reliance on the orientation of a subject-centered perspective. Such approaches fail to fully acknowledge that "valid norms must deserve recognition from all concerned" and instead presents a conception of moral norms in which the "process of judging is relative to the vantage point and perspective of some and not all concerned." ${ }^{25}$ Moreover, Habermas' approach openly acknowledges the situated nature of the participants to discourse, and therefore attempts to avoid the monological and transcendental dimensions of the Kantian tradition. As Habermas writes: "Discourses take place in particular social contexts and are subject to the limitations of time and space...their participants are not Kant's intelligible characters but real human beings." ${ }^{26}$ In alternatively proposing a principle that "constrains all affected to adopt the perspectives of all others in the balance of interests" one can read Habermas as following up on the Hegelian critique of the 'abstract universal' of Kantian morality that had initially suggested an attentiveness to the inter-subjective dimension of interaction so central to the overall project of communicative action. ${ }^{27}$ Within the domain of our concerns over the question of inclusion, this aspect of Habermas' theory importantly tethers the approach of discourse ethics and grounds the criteria of the inter-subjective validation of norms in the situated nature of participants.

\footnotetext{
${ }^{24}$ Jürgen Habermas, Moral Consciousness and Communicative Action, 65. Original Emphasis.

25 Jürgen Habermas, Moral Consciousness and Communicative Action,65. Original Emphasis.

${ }^{26}$ Jürgen Habermas, Moral Consciousness and Communicative Action, 92.

27 Jürgen Habermas, Theory and Practice, trans. J. Viertel (Boston: Beacon Press, 1988), 144-46. Jürgen Habermas, Moral Consciousness and Communicative Action, 65.
} 
In turning to the evaluation of the norms underlying the prerogatives of national territory and state sovereignty, we should begin by briefly drawing attention to the implicit forms of ethical justification that underwrite our contemporary understandings of citizenship and national communities. The claims of modern states to exercise control over their borders and define the limits of community membership extend from the logic of self-determination-itself rooted in the idea of democratic legitimacy and popular sovereignty. ${ }^{28}$ The basis of this understanding of self-determination is put succinctly by Michael Walzer in his description of the state as "constituted by the union of people and government, and it is the state that claims against all other states the twin rights of territorial integrity and political sovereignty." ${ }^{29}$ Under this mode of justification, the prerogatives of territorial control and the demarcation of citizenship stem from the right of a nation or people to determine the structure and form of their mode of collective life. In this sense, it is by appeal to the claim of self-determination that the exclusion of the asylum seeker and refugee are purportedly legitimated by the traditional norms of national sovereignty. Moreover, from the standpoint of citizenship, one might infer that part of the moral justification of the bounded nature of states would have to be tied up with the claim of all to membership. In this sense, the claim to community, which must clearly imply the exclusion of those outside the boundaries of such a group, is supposedly redeemed by the expectation that those without have recourse to their own forms of self-determining political membership. At least as much seems to be implied in the somewhat euphemistic term of 'displaced persons' -as if the issues posed by statelessness were merely the products of disturbances of the interstate system, rather then symptomatic of deeper problems. ${ }^{30}$ However, in this context it is crucial to note that in understanding the claim to community as both a normative and a moral demand, we need to recognize that the universalizing dimension of such an appeal must be directed both to those within and those outside particular polities. But as we have seen in our earlier interrogation of the relation of citizenship to the state, the production of refugees seems to be inherent in the logic of our contemporary forms of community. How are we to reconcile the status of the modern state as the underlying source of the crisis of statelessness, and as the only means by which a 'right to have rights' may be secured?

Having laid out in broad outline the current structure of presumptions that underwrite our contemporary understanding of citizenship and polity, it should be apparent that the framework of discourse ethics forces us to re-evaluate the legitimacy of such norms. From the

\footnotetext{
${ }^{28}$ Such norms are woven into our current structures of international order in the form of the central role respect for state sovereignty occupies in the UN Charter.

${ }^{29}$ Michael Walzer, "The Moral Standing of States: A Response to Four Critics," Philosophy and Public Affairs, Vol. 9, No. 3 (1980): 212.

${ }^{30}$ On this, see Goodwin-Gill's discussion of the postwar re-emergence of the term displaced person, and its initial use as a surrogate for what were essentially refugees of the conflict in Indo-china.

Guy Goodwin-Gill, The Refugee in International Law (Oxford: Oxford University Press, 1998), 11-13.
} 
impartial and inclusive perspective suggested by discourse ethics, the normative privileging of the position of the citizen cannot simply be presumed, while the sovereign prerogatives of the state to control entrance and limit citizenship are now in need of substantial justification. In asking us to consider whether our current norms of citizenship and sovereignty would be accepted by all those effected by such norms, we must clearly take into consideration the position of those who are most disadvantaged by such institutions and who find themselves asymmetrically located in relation to citizens - that is, at the periphery or outside the bounds of inclusion. In this appropriation of discourse ethics, normative justification cannot be merely circumscribed to the concerns of those within political communities, but must come to account for those without. Moreover, while our reading of Arendt brought to the fore the factors producing statelessness at its emergence as a mass phenomenon, at our current historical juncture the claims to validity of such norms have only become more problematic as the idea and integrity of the nation state has itself become conceptually dubious. The question that discourse ethics asks us to raise is whether the norms of sovereignty and self-determination that allow individual states to set the criteria of entrance and control the distribution of citizenship can be fully justified when the perspective of the refugee is taken into account. In a sense, the issue of whether the number of claimants who fulfill the qualifications for the status of asylum seekers or refugees are actually admitted by states that claim to adhere to human rights is actually secondary for our current considerations. From the perspective of discourse ethics, the real question is whether such stringent and exclusionary criteria can be justified at all.

When taking into consideration the perspective of those caught in between communities or who find themselves admitted under a precarious or illicit status-asylum seekers, refugees, immigrants-we have good reason to doubt the acceptability of contemporary norms of citizenship and territorial sovereignty. Indeed, if our foregoing analysis is correct in suggesting a fundamental relation between our current modalities of community and citizenship with the practices of exclusion that produce stateless, we have good reason to believe that a moral imperative exists for weakening the boundaries of states and liberalizing the means of gaining membership within communities. While still allowing for the values of cultural integrity and communal life, a consideration of the question of inclusion from the position of all those affected by the exclusionary norms of membership will clearly push us to take up a more cosmopolitan perspective. One form this might take is in the recognition of a fundamental right to claim citizenship within a polity-with the burden of proof against such a claim lying on the part of the state. The development and articulation of such a right to belong would not necessarily be incompatible with some forms of communal integrity. However such claims will have to be justified in relation to the claims of those outside of a particular state, and not simply decided in advance by the presumptive bias of the national interest.

As I have tried to indicate in the foregoing discussion, the approach of discourse ethics when universally applied to the realm of those affected by our contemporary norms of citizenship and sovereignty forces us to reconsider the contours of our current practices. However, I would also like to suggest that the formal dimensions of discourse ethics raise certain issues for our attempt to address the particular concerns brought to the fore by statelessness and point to 
the limitations that such an engagement will have to overcome. As Habermas himself notes of his approach, the principle of discourse ethics is procedural rather then substantive in form, making reference to the discursive process of the evaluation of normative claims to validity. As he writes:

To this extent discourse ethics can properly be characterized as formal...Practical discourse is not a procedure for generating justified norms but a procedure for testing the validity of norms that are being proposed and hypothetically considered for adoption. That means that practical discourses depend on content brought to them from the outside. ${ }^{31}$

Thus, much like the Kantian conception of morality based on the categorical imperative that it aims to supercede, discourse ethics itself is not aimed at the generation of moral norms, but rather offers a way of evaluating and potentially legitimating norms that are brought into question. However as we have noted above, unlike the monological dimension of the Kantian approach, Habermas explicitly constructs discourse ethics around a communicative model, thereby explicitly emphasizing the dimension of inter-subjective agreement between a community of participants. Yet the very virtue of discourse ethics in attempting to base the validation of norms in the actual participation of concrete agents in practical discourse itself raises questions about how the realm of participants is constituted. As Habermas notes, the very idea of practical discourse is dependent on a "horizon provided by the lifeworld of a specific social group..." and thereby tied to particularized conceptions of community. ${ }^{32}$ Moreover, the very means in which the norm in question is itself conceptualized-a matter of economics, of immigration, of human rights-seems to radically shift our sense of the scope of relevant participants, and indeed points to the question of how those bounds are themselves politically constituted. An instructive example of this is the gradual shift we have seen in the past few decades in the refugee policies of many Western industrial democracies. Arguably, there has been a widespread move in policy away from conceptualizing such issues as concerning human rights, and toward treating the claims of refugees and asylum seekers primarily as an immigration question. Such trends are exemplified more recently in the emergence of policies designed to deflect claimants without violating international obligations, such as the Safe Third Country Agreement between the United States and Canada. ${ }^{33}$ These developments of course imply the normative privileging of the position of citizens by more fully excluding potential claimants themselves from the realm of parties whose views and positions are fully relevant to the formulation of policy. Such issues only highlight the possible difficulties in addressing what it would mean to have stateless persons play a role in the adjudication of the norms that would secure their inclusion in the first place. The potentiality of discourse

\footnotetext{
31 Jürgen Habermas, Moral Consciousness and Communicative Action, 103.

32 Jürgen Habermas, Moral Consciousness and Communicative Action, 103.

${ }^{33}$ Allan Thompson, “Unfair refugee accord should be struck down," Toronto Star, January 26, 2008.
} 
ethics to validate new and intrinsically open forms of community is clear from our earlier discussion, but from our contemporary standpoint we seem terribly far from having adopted the "enlarged mentality" that the implementation of such considerations would seem to demand. Moreover, the rootedness of our fundamental conceptions of democratic legitimacy in the idea of bounded communities makes the leap to the standpoint of 'citizen of the world,' or even to a post-national consciousness, seemingly rather distant. This suggests that addressing the issue of statelessness in the present requires that we direct our attention toward problematizing the very notions of citizen and 'people' that seemingly necessitate political closure.

\section{THEORIZING the CONTINGENCY AND CONTESTABILITY OF COMMUNITY:}

Having drawn attention to the potential and limits of discourse ethics to point the way toward more inclusive understandings of community and citizenship, we will now engage with the emergent perspective of agonistic democratic theorists in order to suggest ways in which the idea of a 'people' itself can be understood as intrinsically open. As indicated above, the central dilemma facing our attempt to overcome the issues posed by statelessness is that the position of the refugee is itself one of exclusion and in a sense constitutes a form of identity which seemingly eludes solidarity. Therefore any attempt to overcome the particular challenges posed by statelessness and the attempt to articulate a fundamental right to belong to community will crucially have to underwrite the modes of inclusion necessary to bring those who fall outside of the community within the threshold of the relevant. It is with this aim in mind that we turn to writers such as William Connolly and Chantal Mouffe, who have helped develop and articulate the agonistic approach toward democratic theory that places the issues of conflict and contestation at the center of the political. Using their insights I will further develop our engagement with the issue of statelessness along three dimensions: the unsettled nature of our concepts of citizen and 'people,' the constitutive tension between liberalism and democracy, and the potentiality for more inclusive and open notions of community that the agonistic vision of politics suggests. These considerations will bring to light how we should understand the basis and bounds of community as always inherently contingent, and therefore help cultivate the orientation necessary to be attentive to the needs of those excluded.

Before beginning our engagement with the work of the aforementioned theorists' it seems best to briefly address and diffuse the apparent opposition that such perspectives have been claimed to have with the approach of deliberative democracy that Habermas' work is associated with. Given the often emphasized challenge that the agonistic conception of democratic politics claims to pose to the approach toward radical democracy stemming from the critical theory of Habermas, the attempt to supplement our understanding of the issue of statelessness by turning to both traditions is in need of some explanation. Chantal Mouffe in particular has continually emphasized the divergences between the agonistic approach toward the political and the understanding of politics expressed in the work of deliberative democrats 
that follow Habermas, with their emphasis on rationalism and consensus. ${ }^{34}$ However, I believe that the claims of Mouffe and others of an extreme divergence between the two approaches are greatly overstated-at least insofar as such claims suggest that we deny the fruitfulness of an engagement between the perspectives. As Simone Chambers writes:

Discourse ethics does not project the ideal of a dispute-free world, nor does it devalue contestation. Not only is such a world unattainable, it is also undesirable. Diversity and difference lead to criticism, and criticism leads to well founded norms. ${ }^{35}$

Positing a radical opposition between the two perspectives and their respective emphasis on the values of political contestation/conflict and consensus obscures how they can be brought together creatively. Moreover, Mouffe's tendency to criticize the consensus-oriented dimension of discourse ethics shows a failure to appreciate the central role of the contestation of norms to Habermas' approach. Such an understanding of his project is echoed in Patchen Markell's reading of Habermas' project as understanding "democratic politics as an unending process of contestation" in which there is a clear recognition that "no actually existing settlement can constitute a satisfactory embodiment of the regulative idea of agreement." ${ }^{36}$ While this is not the place to develop a full response to Habermas' detractors, the notions of disagreement and dissent play important roles in Habermas' theory which are often obscured by readings that tend to mistakenly classify his work along with that of Rawls. ${ }^{37}$ However, such commentators are right insofar as they contend that the agonistic approach does provide us with a critical purchase on particular elements of political practice by distinctively emphasizing a model of politics centered around conflict, and it is precisely this focus we should engage with to supplement our developing approach toward statelessness.

Having indicated the general direction of my engagement with agonistic perspectives, I would like to first turn to William Connolly's analysis of the inherently contested nature of our central political concepts in his book The Terms of Political Discourse. One of Connolly's central aims in this work is to challenge the prevalent assumption within the social sciences that the language of politics is somehow a neutral medium that merely coveys meaning and to "focus attention

\footnotetext{
${ }^{34}$ Chantal Mouffe, On the Political (New York: Routledge, 2005), 12-13.

${ }^{35}$ Simone Chambers, Reasonable Democracy: Jurgen Habermas and the Politics of Discourse (Ithaca: Cornell University Press, 1996), 162.

${ }^{36}$ Patchen Markell, “Contesting Consensus: Rereading Habermas on the Public Sphere,” Constellations, Vol. 3, No. 3 (1997): 379.

${ }^{37}$ The role of conflict in his thought is perhaps most pronounced in his theorizing of the public sphere as domain of contestation or "medium for permanent criticism". (Theory of Communicative Action, 2, 341)

Indeed, reading the public sphere as the domain where the domination of public debate by organized political and economic interest is challenged and contested by citizens further emphasizes this connection.
} 
on the locus of space for contestation" that exists within "the fine meshes of social and political vocabularies themselves." ${ }^{38}$ Taking an expressivist perspective on language, Connolly draws our attention to the fact that discussions over the "correct use of partly shared appraisal concepts are themselves an intrinsic part of politics" and introduces the idea of "essentially contested concepts' to denote such terms. ${ }^{39}$ In this way, he carefully frames his analysis of political discourse in opposition to what he calls 'empiricist' or 'rationalist' tendencies within political science in order to highlight the deeply political valence of our arguments over the use of such words as democracy, power and freedom. Connolly's emphasis on the potentialities of contestation and the internal discord within our political language emphasizes a certain vision of the political as essentially open. As he writes:

Politics is, at its best, simultaneously a medium in which unsettled dimensions of a common life find expression and a mode by which a temporary or permanent settlement is sometimes achieved. $^{40}$

Thus, perhaps most importantly for our purposes, Connolly's work highlights the political dimension of language itself in ways that enable us to track potential opportunities for political innovation by allowing us to "expose conceptual closure when it has been imposed artificially." ${ }^{41}$ In this way, what Connolly's analysis forces us to confront is the continually partial and incomplete nature of our core political concepts. This suggests that the extension and meaning of such concepts as community and citizenship can never be said to be fully decided, while our understandings of such central ideas as 'justice' at any specific moment are to be understood as always the conception of a particular group and therefore always open to contestation and further negotiation. In this way, distancing ourselves from the approach toward our social world that treats such questions as static and 'operationalizable' allows us to see that our central concepts are not anymore settled than the actual communities within which we live.

Connolly's insights on the inherent contestability of our central political concepts has a central import for our discussion of how we might overcome the forms of exclusion that produce the situation of statelessness. In particular, the very idea of the bounds of a 'people' and the notion of citizenship are revealed as themselves highly contested in the very way Connolly's analysis suggests. In no context attuned to the complexities of our political landscape can we truly speak

\footnotetext{
${ }^{38}$ William Connolly, The Terms of Political Discourse, 231.

${ }^{39}$ William Connolly, The Terms of Political Discourse, 39.
}

The phrase 'essentially contest concept' is used to refer to case in which 'the concept involved is appraisive in that the state of affairs it describes is a valued achievement, when the practice internally complex in that it's characterization involves reference to several dimensions, and when the agreed and contested rules of application are relatively open, enabling parties to interpret even those shared rules differently as new and unforeseen situations arise." (ibid, 10)

${ }^{40}$ William Connolly, The Terms of Political Discourse, 227.

${ }^{41}$ William Connolly, The Terms of Political Discourse, 231. 
of the category of citizen as having a fixed nature, or of a particular shibboleth-whether of language, ethnicity, race, nationality, gender or class-that defines the bounds of political membership once and for all. The disputed and variable status of the idea of the citizen is echoed in the work of Judith Shklar, who has pointed out that "there is no notion more central in politics than citizenship, and none more variable in history or contested in theory." ${ }^{12}$ While on some banal level citizenship can be understood as a particular relationship between the individual and the state, the contours of that membership and the status it confers have varied widely through the tradition of western thought. Such sentiments regarding the contingent and potential variability of our social practices of inclusion and exclusion are brought to mind in Chantal Mouffe's statement that:

What is at a given moment considered the 'natural order'- jointly with the 'common sense' which accompanies it - is the result of sedimented practices; it is never the manifestation of a deeper objectivity exterior to the practices that bring it into being. ${ }^{43}$

Placing this dimension of contestability at the center of our thinking about citizenship therefore helps us keep in mind the inherent contingency to any idea of a 'people' and allows us to cultivate a sense of solidarity with those outside our particular form of community by viewing them always as potential citizens with legitimate claims to our concern.

Having offered an account of how the valence of contestability can begin to orient us toward intrinsically more open conceptions of community, I would like to now attend to the elements of the tradition of agonistic theory that emphasis the central role of conflict and antagonism to the realm of the political more generally. Much like Connolly, the work of Mouffe also centers around the radical potentiality of a conception of politics that emphasizes the value of contestation for forestalling the threat of closure that seemingly haunts our democratic practices. However, Mouffe in particular carries the thematic of contestation to the extreme in order to argue for the irreducibility and ineliminability of the potential for antagonism within the domain of the political. Mouffe's antagonistic conception of politics is in part indebted to a tempered engagement with the work of Carl Schmitt that draws off his insistence on the fundamentally "conflictual nature of politics" and the importance of recognizing the antagonistic and relational basis of identity, while rejecting his insistence on the "existence of a homogenous demos. ${ }^{\prime 44}$ According to Mouffe, this revised vision of politics centered around the ever-present possibility of conflict is both more in tune with the oppositional foundation of identity and more open to the potentials for radical challenge and transformation that democracy allows.

\footnotetext{
42 Judith Shklar, American Citizenship: The Quest for Inclusion (Cambridge: Harvard Press, 1991), 1.

${ }^{43}$ Chantal Mouffe, On the Political, 18.

${ }^{44}$ Chantal Mouffe, On the Political, 13-14.
} 
Within Mouffe's interpretation of modern democracy, our fundamental framework of political activity is structured by the paradoxical tension between democracy as a form of rule and the symbolic framework of legalism, rights, and equality, that characterizes liberalism. ${ }^{45}$ Drawing off the insights of Schmitt's critique of the liberal understanding of politics while rejecting his dismissal of liberalism, Mouffe emphasizes how this 'democratic paradox' between the two components of our modern framework of politics leads to a permanent site of tension, for "no final resolution between these two conflicting logics is possible" with our options limited to only precarious and temporary negotiations of this divide. ${ }^{46}$ More fundamentally, we can read Mouffe's identification of the conflicting logic of liberal democracy as part of the deeper tension between legality and the sovereign will of the demos. The signature of this conflict runs like a red thread through the history of political theory. Emblematic of this are Aristotle's discussions in the Politics of the tension between the will of the people and the laws of the polity, as well as Rousseau's opaque considerations on how to resolve that tension in a period at which liberalism was more a nascent theory than an established tradition. ${ }^{47}$ Yet Mouffe does helpfully flag how this tension is itself deepened by the advent of liberalism and its emphasis on equality and rights discourse. As Mouffe notes:

By constantly challenging the relations of inclusion-exclusion implied by the political constitution of the 'people'-required by the exercise of democracy-the liberal discourse of universal human rights plays an important role in maintaining the democratic contestation alive. On the other side, it is only thanks to the democratic logics of equivalence that frontiers can be created and a demos established without which no real exercise of rights would be possible. $^{48}$

By dramatizing the site of liberal democracy as contingent and unstable, her analysis brings to the fore the radically precarious and problematic dimension of any attempt to permanently articulate more inclusive and open conceptions of community. Moreover, Mouffe's warning regarding the fragility of any particular political configuration is exceedingly apt in our current age of the 'war on terror' when the civil rights of citizens, let alone those of resident aliens and non-nationals, have been notably eroded under more or less democratic institutions. As she notes of political negotiations in general, "every order is the temporary and precarious articulation of contingent practices" - a point that emphasizes the provisional and limited character of any political 'solution. ${ }^{49}$ Such observations speak directly to the concerns at hand by asking us to temper the cosmopolitan aspirations and pretensions of any project with the

${ }^{45}$ Chantal Mouffe, The Democratic Paradox (New York: Verso, 2000), 2.

${ }^{46}$ Chantal Mouffe, The Democratic Paradox, 45.

${ }^{47}$ Aristotle, The Politics, trans. Carnes Lord (Chicago: University of Chicago Press, 1985), 1292al.

Jean-Jacques Rousseau, The Social Contract and The First and Second Discourses, trans. Susan Dunn (New Haven: Yale University Press, 2002), 80-3.

${ }^{48}$ Chantal Mouffe, The Democratic Paradox, 10.

${ }^{49}$ Chantal Mouffe, On the Political, 18. 
recognition that the negotiation of the terms of political membership is always inherently an ongoing political project and can never be considered a fait accompli. Recognizing that the universalizing tendencies of liberalism and human rights discourse exist in tension with the potentialities of popular sovereignty brings to light the ever present potential to reconstitute more open notions of community membership necessary to secure a 'right to belong,' while also stressing the precariousness of such arrangements.

\section{CONCLUSION: TOWARD PRACTICES OF INCLUSION}

Our aforementioned reading of theorists from within the agonistic tradition of radical democracy has attempted to illustrate how an understanding of the political centered around conflict and contestation can be put to the uses of overcoming the conditions that produces statelessness in our contemporary world. Such an engagement arguably provides a needed supplement to the Habermassian approach toward statelessness by positing new modalities for understanding citizenship as intrinsically open, and therefore provides a basis for including those presently excluded from our forms of community in our realm of moral concern. However, while our discussion of agonism has highlighted the essentially contestable nature of claims to collective identity, it is crucial to emphasize that such contestability is not equally open to all. This is a crucial insight that is emphasized in Lawrie Balfour's recent project of putting agonistic theory and reparations politics into conversation, because it brings to the fore the limitations of our own attempt to engage with the tradition of agonistic theory to diagnose the pathologies of exclusionary citizenship practices. As Balfour saliently points out:

Even if all identities are ultimately unstable or contestable, even if they are all produced through rather than revealing foundational truths about individuals or communities, they are neither produced in the same way or contestable to the same degree. To assume that they are is to overlook crucial asymmetries between members of different identity groups. ${ }^{50}$

Within the context of our current discussion, such considerations draw attention to the fact that it is just those who are most disadvantaged by our current practices of citizenship who shall also be least able to challenge the norms that produce contemporary forms of exclusion. While the agonistic lens provides a powerful perspective for destabilizing and challenging our conceptions of community, we must also remain attentive to how the potentiality for contestation is often structurally determined. Remaining cognizant of this issue emphasizes the importance of developing forms and practices of solidarity as part of the project of reconceptualizing our notions of citizenship. Such considerations suggest that the limitations of

\footnotetext{
${ }^{50}$ Lawrie Balfour, "Act and Fact: Slavery Reparations as a Democratic Politics of Reconciliation," in The Politics of Reconciliation in Multicultural Societies, ed. W. Kymlicka and B. Bashir (Oxford: Oxford University Press, 2008), 99.
} 
the agonistic perspective point to the need to foster local potentialities of community in ways that may allow us to transcend the problematic bounds of the state and build the forms of solidarity necessary for more inclusive orientations of citizenship. While such potentialities remain fragmentary and uncertain at present, such experiments in developing alternative practices of citizenship will have to play a central role in any practical attempt to grapple with the issues raised by statelessness. 